\title{
DESAIN DIDAKTIS BERBASIS PERMAINAN \\ TRADISIONAL ENGKLEK DI SEKOLAH DASAR
}

\author{
Revina Putri Hermawan
}

Universitas Pendidikan Indonesia

revinaph@upi.edu

Epon Nur'aeni

Universitas Pendidikan Indonesia

nuraeni@upi.edu

Ika Fitri Apriani

Universitas Pendidikan Indonesia

apriani25@upi.edu

Abstract

This research motivated by the findings of learning obstacles experienced students in material around square. This is known based on the results of test questions conducted during preliminary study to fourth grade elementary school students. To overcome learning obstacles experienced by students, researchers will design a didactic design. The purpose of this study is to describe the didactic design on the material around square and describe the students' responses the implementation of didactic design. The didactic design can be interpreted learning design that emphasizes the didactic aspect, namely the teacher's teaching method. This study uses method with a Didactical Design Research (DDR) research design consisting of three research stages, namely a prospective analysis of the didactic situation before learning (prospective analysis) in the form of a Hypothetical Didactic Design including ADP (Pedagogical Didactic Analysis), metapedadidactive analysis, and retrospective analysis (retrospective analysis), with data collection techniques used in the form of interviews, observations, and attitude scales. The research subjects were 26 students in grades $I V$ and $V I$ and 1 teacher for grade $I V$ at SDN 1 Sindangrasa. Based on results of study, through application of the didactic design carried out in stages I and II, can help overcome learning obstacles experienced by students in the material around a square. This is shown from the students' responses on the attitude scale, results of the LAS (Student Activity Sheet) work and interviews with teachers. In addition, didactic design is able to create a fun and meaningful learning atmosphere for students.

Keywords: learning obstacle, didactical design research, square, meaningful learning, $L A S$ 
Abstrak

Penelitian ini dilatarbelakangi oleh adanya temuan learning obstacle yang dialami siswa pada materi keliling persegi. Hal ini diketahui berdasarkan hasil soal tes yang dilakukan pada saat studi pendahuluan kepada siswa kelas IV Sekolah Dasar. Untuk mengatasi learning obstacle yang dialami siswa, peneliti akan merancang sebuah desain didaktis. Tujuan dari penelitian ini adalah untuk mendeskripsikan desain didaktis pada materi keliling persegi serta memaparkan respon siswa dan guru terhadap implementasi desain didaktis tersebut. Desain didaktis dapat diartikan sebagai desain pembelajaran yang lebih menekankan pada aspek didaktik yakni cara pengajaran guru. Penelitian ini menggunakan metode Didactical Design Research (DDR) yang terdiri dari tiga tahap penelitian, yakni analisis situasi didaktis sebelum pembelajaran (prospective analysis) berupa Desain Didaktis Hipotesis termasuk ADP (Analisis Didaktis Pedagogis), analisis metapedadidaktif, dan analisis retrospektif (retrospective analysis), dengan teknik pengumpulan data yang digunakan berupa wawancara, observasi, dan skala sikap. Subjek penelitian yaitu 26 siswa kelas IV dan VI serta 1 guru kelas IV SDN 1 Sindangrasa. Berdasarkan hasil penelitian, melalui penerapan desain didaktis yang dilakukan pada tahap I dan II dapat membantu mengatasi learning obstacle yang dialami siswa pada materi keliling persegi. Hal ini ditunjukkan dari respon siswa pada skala sikap, hasil pengerjaan LAS (Lembar Aktivitas Siswa) serta wawancara terhadap guru. Selain itu, desain didaktis mampu menciptakan suasana pembelajaran yang menyenangkan dan bermakna bagi siswa.

Kata kunci : hambatan belajar, desain didaktis, persegi, pembelajaran bermakna, LAS

\section{PENDAHULUAN}

Ruang lingkup materi geometri terdiri dari titik, garis, bidang, ruang, sudut, koordinat titik, bangun datar, bangun ruang serta pengukuran ${ }^{1}$. Di sekolah dasar materi ini diajarkan dari mulai kelas I hingga kelas VI, diawali dengan pengenalan bangun datar dan bangun ruang sampai pada rumusan keliling dan luas daerah bangun tersebut. Materi geometri merupakan bagian dari materi matematika dengan jumlah porsi materi terbanyak dibandingkan dengan materi lain, walaupun

\footnotetext{
${ }^{1}$ Epon Nur'aeni, Konsep Dasar Geometri (Bandung: Hibah Buku UPI, 2016).
} 
demikian materi ini seringkali dianggap sebagai materi yang sulit dipahami oleh siswa. Menurut 2 penyebab kesulitannya adalah pemahaman siswa masih berada pada tahap operasional konkret sedangkan materi geometri bersifat kompleks didalamnya terdapat banyak simbol dan operasi yang formal. Sejalan dengan itu ${ }^{3}$ menyatakan bahwa masih banyak ditemukan siswa yang mengalami missconcept dalam materi geometri. Miskonsepsi ditunjukkan sebagai hambatan belajar siswa.

Hambatan belajar pada materi geometri di sekolah dasar terjadi pada siswa kelas IV pada materi keliling persegi. Hal ini diketahui berdasarkan temuan di lapangan. Pada saat siswa diberikan soal tes sebanyak 5 soal yang berkaitan dengan keliling persegi, siswa merasa kesulitan dalam menjawab soal-soal yang diberikan. Learning obstacle atau hambatan yang dialami siswa pada materi keliling persegi, dikategorikan menjadi 4 tipe yakni:

1. Tipe 1: Learning Obstacle terkait pemahaman siswa tentang konsep bangun datar persegi. Pada tipe ini, siswa merasa kebingungan ketika diberikan soal tentang konsep bentuk bangun datar, pasalnya siswa tidak dapat membedakan antara bentuk persegi dengan persegi panjang.

2. Tipe 2 : Learning Obstacle terkait dengan konsep rumus keliling persegi. Pada tipe ini, siswa tidak mengetahui dan memahami konsep rumus keliling persegi, saat diberikan soal menentukan rumus keliling persegi siswa kesulitan dalam menyelesaikan soal tersebut.

3. Tipe 3 : Learning Obstacle terkait dengan menghitung keliling persegi. Pada tipe ini, siswa kesulitan dalam menyelesaikan soal tentang menghitung ukuran setiap sisi persegi yang telah diketahui kelilingnya. Siswa menuliskan jawaban yang kurang tepat.

4. Tipe 4 : Learning Obstacle terkait dengan pemahaman pada soal cerita keliling persegi. Learning Obstacle yang dialami siswa yaitu siswa hanya menghitung angka yang terdapat pada soal tanpa memahami apa yang ditanyakan pada soal cerita.

Bersamaan dengan itu, wawancara dilakukan kepada wali kelas, kelas IV untuk mengetahui penyebab terjadinya hambatan belajar yang dialami siswa pada materi tersebut. Berdasarkan hasil wawancara, penyebabnya adalah karena kemampuan daya ingat siswa yang rendah

2 Irfan Fauzi and Andika Arisetyawan, "Analisis Kesulitan Belajar Siswa Pada Materi Geometri Di Sekolah Dasar," Jurnal Matematika Kreat 11, no. 1 (2020): 27-35.

${ }^{3}$ Zeerin Tastbita, Epon Nur'aeni, and Akhmad Nugraha, "Learning Obstacle Siswa Pada Materi Luas Daerah Persegi Panjang" 7, no. 2 (2020): 138-147. 
sehingga kesulitan dalam menentukan rumus. Selain itu, siswa mengalami kesulitan dalam menyelesaikan operasi hitung perkalian dan pembagian dalam materi keliling persegi, hal ini menandakan siswa belum memahami materi sebelumnya secara ut uh ${ }^{4}$. Peneliti pun mengamati siswa pada saat kegiat an pembelajaran, terlihat siswa memiliki semangat yang rendah dan kurangnya kepercayaan diri siswa dalam menyelesaikan setiap soal yang diberikan, peneliti menduga hal ini pun menjadi faktor lain yang mempengaruhi terjadinya hambatan belajar. Rendahnya semangat siswa disebabkan karena belum optimalnya guru dalam penggunaan media pembelajaran dan bahan ajar ${ }^{5}$ sehingga siswa merasa jenuh dalam mengikuti pembelajaran. Dalam hal ini, kemampuan guru dalam mengemas pembelajaran yang bermakna dan menyenangkan sangat penting dilakukan ${ }^{6}$.

Berdasarkan penjelasan di atas tujuan dari penelitian ini adalah untuk mendeskripsikan desain didaktis pada materi keliling persegi yang dilatarbelakangi oleh adanya temuan learning obstacle yang dialami siswa kelas IV Sekolah Dasar pada materi keliling persegi dan memaparkan respon siswa dan guru terhadap implementasi desain didaktis tersebut. Desain didaktis merupakan pengembangan desain pembelajaran yang lebih menekankan pada aspek didaktik dengan mengacu pada teori pembelajaran yang relevan ${ }^{7}$. Desain didaktis sangat efektif untuk mengatasi learning obstacle yang dialami siswa ${ }^{8}$

Metode yang digunakan dalam penelitian ini adalah Metode desain didaktis (Didactical Design Research) dalam materi keliling persegi.

${ }^{4}$ Arni Kholiyanti, "Pembelajaran Matematika Dari Konkrit Ke Abstrak Dalam Membangun Konsep Dasar Geometri Bagi Siswa Sekolah Dasar," Mathematics Education Journal 1, no. 2 (2018): 40-46.

5 Permata Wulan Sari and Nyiayu Fahriza Fuadiah, "ANALISIS LEARNING OBSTACLE MATERI SEGITIGA," Jurnal Inovasi Pendidikan Matematika 2, no. 1 (2019): 21 29.

6 Muslimin, Ratu Ilma Indra Putri, and Somakim, "Desain Pembelajaran Pengurangan Bilangan Bulat Melalui Permainan Tradisional Congklak Berbasis Pendidikan Matematika Realistik Indonesia Di Kelas IV Sekolah Dasar," Jurnal KREANO 3, no. 2 (2012): 100-112.

7 Muiz Abdul Dindin Lidinillah, "Educational Design Research : A Theoretical Framework for Action," no. 1 (2012): 23.

8 Vira Pratiwi, Dian Indihadi, and Dindin Abdul Muiz Lidinillah, "Strategi Think Talk Write Untuk Pengembangan Kemampuan Komunikasi Matematis Siswa Pada Materi Perbandingan Di Kelas V SD," PEDADIDAKTIKA: Jurnal IImiah Pendidikan Guru Sekolah Dasar 2, no. 2 (2015): 243-258. 
Menurut ${ }^{9}$ penelitian Didatical Design Research memiliki 3 tahap yang harus dilakukan, diantaranya tahap pertama prospective analysis yaitu menganalisis situasi didaktis sebelum pembelajaran, tahap kedua analisis metapedadidaktik, tahap ketiga restrospective analysis yaitu analisis yang mengaitkan prospective analysis dengan hasil analisis metapedadidaktik. Penelitian ini dilakukan di SDN 1 Sindangrasa dengan subjek penelitian ini adalah 26 siswa kelas IV dan VI dan guru kelas IV SDN 1 Sindangrasa. Pemilihan subjek penelitian disesuaikan pada fokus penelitian yang telah dipilih peneliti yang merupakan materi pembelajaran yang dianggap sulit oleh siswa dan kemungkinan besar siswa mengalami hambatan belajar dalam memahami materi tersebut. Instrumen yang digunakan dalam penelitian ini adalah observasi, skala sikap dan wawancara. Ketiga instrumen tersebut telah divalidasi oleh para ahli yakni dosen ahli bidang matematika. Instrumen skala sikap dan wawancara dibuat untuk mengetahui respon siswa dan guru terhadap implementasi desain didaktis yang telah dibuat oleh peneliti. Skala sikap terdiri dari 15 nomor yang berkaitan dengan respon siswa terhadap pelaksanaan pembelajaran menggunakan model pembelajaran SPADE yang didalamnya berbasis permainan tradisional engklek dan respon siswa terhadap penggunaan LAS dalam pembelajaran. Sedangkan, instrumen wawancara dibuat untuk mengetahui tanggapan, pendapat guru terhadap pelaksanaan desain didaktis dalam mengajarkan materi keliling persegi. Wawancara yang digunakan adalah wawancara terstruktur dengan mengambil sebuah data menggunakan pedoman wawancara, wawancara terdiri dari 7 pertanyaan. Secara umum, pertanyaan wawancara berkaitan dengan manfaat implmentasi desain didaktis pada materi keliling persegi dengan menggunakan model pembelajaran SPADE dan penggunaan LAS dalam pembelajaran yang membantu siswa mengatasi learning obstacle yang dialami siswa pada materi keliling persegi.

Implementasi desain didaktis tahap I dan II dilakukan di halaman PAUD AL-Muwaqif. Sedangkan kegiatan wawancara dilakukan secara langsung dengan menemui guru kelas IV di sekolah. Teknik analisis data menggunakan model Miles dan Huberman dalam ${ }^{10}$ yakni reduksi data, penyajian data serta penarikan kesimpulan.

9 Didi Suryadi, "Didactical Design Research (DDR) Dalam Pengembangan Pembelajaran Matematika," Prosiding Seminar Nasional Matematika STKIP Siliwangi Bandung (2013): 3-12.

${ }^{10}$ Frans Pantan and Priskila Issak Benyamin, "Peran Keluarga Dalam Pendidikan Anak Pada Masa Pandemi Covid-19," Jurnal Teologi Pantekosta 3, no. 1 (2020): 13-24. 


\section{PEMBAHASAN}

Desain didaktis Keliling Persegi berbasis Permainan Tradisional Engklek

Desain didaktis yang dirancang dilatarbelakangi adanya temuan learning obstacle yang dialami siswa pada materi keliling persegi. Learning obstacle ini disebabkan karena beberapa faktor diantaranya karena pengetahuan yang dimiliki siswa terbatas, kesiapan siswa yang cenderung kurang dalam pembelajaran serta faktor didaktik atau cara mengajar guru. Cara pengajaran guru mampu mempengaruhi performa siswa ${ }^{11}$ Maka, dengan memperhatikan hambatan belajar yang dialami siswa beserta faktor-faktor penyebabnya, peneliti akan merancang sebuah bahan ajar berupa LAS (Lembar Aktivitas Siswa) dan RPP (Rencana Pelaksanaan Pembelajaran). LAS dirancang dengan mengikuti tahapan model pembelajaran yang dipilih peneliti yakni model pembelajaran SPADE yang terdiri dari 5 tahapan atau aktivitas pembelajaran yaitu 12 Aktivitas 1 Singing, Aktivitas 2 Playing, Aktivitas 3 Analyzing, Aktivitas 4 Discussing, dan Aktivitas 5 Evaluating. Penerapan LAS dalam pembelajaran terdapat pada kegiatan inti, LAS dijadikan sebagai acuan siswa saat mengikuti aktivitas dalam pembelajaran materi keliling persegi.

Desain didaktis dibuat dengan memperhatikan teori-teori yang relevan dengan karakteristik siswa sekolah dasar. Teori yang menjadi pijakan dalam penyusunan desain didaktis diantaranya teori yang dikemukakan oleh teori Piaget dan teori Dienes. Piaget dalam 13 menyebutkan bahwa perkembangan koginitif terbagi menjadi 4 tahapan, bagi siswa sekolah dasar dengan rentang usia 7 sampai 12 tahun berada pada tahap operasional konkret, karakteristik dari tahapan ini yaitu anak sudah mulai memahami operasi secara logis dibantu oleh benda-benda konkret. Dienes dalam ${ }^{14}$ menjelaskan bahwa proses pembelajaran matematika dapat dibangun melalui aktivitas bermain ${ }^{15}$.

11 Wahid Yunianto, Rully Charitas Indra Prahmana, and Cosette Crisan, “Indonesian Mathematics Teachers' Knowledge of Content and Students of Area and Perimeter of Rectangle," Journal on Mathematics Education 12, no. 2 (2021): 223-238.

12 Epon Nur'aeni et al., "SPADE : Model Pembelajaran Geometri Di Sekolah Dasar," Indonesian Journal of Primary Education 4, no. 2 (2020): 81-88.

13 Tatang Herman, Karlimah, and Komariah, Pendidikan Matematika 1 (Bandung: UPI Press, 2007).

14 Ibid.

${ }^{15}$ Susan Rauchwerk, "Learning Through Play in Speed School , an International Accelerated Learning Program," International Journal of Learning, Teaching and Educational Research 16, no. 6 (2017): 52-63. 
Sedangkan RPP dibuat agar proses pembelajaran dapat berjalan secara efektif dan terarah serta mencapai tujuan pembelajaran yang telah ditentukan. Tujuan pembelajaran ditentukan dari Indikator Pencapaian Kompetensi (IPK) yang diturunkan dari Kompetensi Dasar (KD) yang terdapat dalam kurikulum 2013. Tujuan pembelajaran dibuat untuk meminimalisir atau mengatasi learning obstacle yang dialami siswa. Tujuan pembelajaran berkolerasi dengan model pembelajaran SPADE. Melalui penerapan desain didaktis diharapkan mampu meminimalisir hambatan belajar siswa pada materi keliling persegi berbasis permainan tradisional engklek menggunakan model pembelajaran SPADE ${ }^{16}$.

\section{Respon Siswa dan Guru terhadap Implementasi Desain didaktis}

Desain didaktis yang telah dirancang oleh peneliti memberikan kesan yang baik bagi guru dan siswa yang menjadi partisipan dalam penelitian ini. Hal ini diketahui berdasarkan hasil tanggapan siswa terhadap jawaban pada instrumen skala sikap dan hasil wawancara guru terhadap implementasi desain didaktis. Skala sikap terdiri dari 15 pertanyaan yang berkaitan dengan respon siswa terhadap penggunaan LAS dalam pembelajaran dan kegiatan pembelajaran berbasis permainan tradisional engklek dalam model pembelajaran SPADE. Peneliti uraikan hasil tanggapan siswa terhadap instrumen skala sikap.

Respon siswa pada pernyataan 1 yang berkaitan dengan pernyataan apakah siswa menyukai pembelajaran matematika yang diawali dengan kegiatan bernyanyi atau tidak. Maka, diperoleh hasil bahwa pada implementasi desain tahap I, sebagian besar siswa menjawab sangat setuju ataupun setuju. Namun, ada pula siswa yang tidak menjawab tidak setuju. Respon siswa terhadap hal ini merupakan suatu hal yang wajar, sebab tidak semua siswa menyukai kegiatan bernyanyi, tergantung pada minat dari masing-masing siswa ${ }^{17}$. Untuk implementasi desain tahap II, seluruh siswa menjawab sangat setuju ataupun setuju, tidak ada yang merespon dengan tidak setuju atau tidak menyukai ketika pembelajaran matematika yang diawali dengan kegiatan bernyanyi, hal ini menandakan bahwa siswa dapat menikmati kegiatan bernyanyi pada awal pembelajaran.

16 Epon Nur'aeni and dkk, Pengembangan Model Pembelajaran Geometri Berbasis Permainan Tradisional Kampung Naga Untuk Siswa Sekolah Dasar (Tasikmalaya: Penelitian Dana Dikti Tahun ke-2, 2019).

17 Ary Woro Kurniasih, Isti Hidayah, and Mohammad Asikin, "Teacher Support for Eliciting Students Mathematical Thinking: Problem Posing, Asking Questions, and Song," International Journal of Learning, Teaching and Educational Research 19, no. 10 (2020): 265-285. 
Respon siswa pada pernyataan 2 yakni berkaitan dengan pernyataan apakah siswa senang belajar matematika sambil bermain engklek. Diperoleh hasil bahwa pada implementasi tahap I dan II, seluruh siswa menjawab sangat setuju maupun setuju. Hal ini membuktikan bahwa melalui aktivitas bermain dapat menumbuhkan semangat siswa saat pembelajaran. Selain itu juga melalui aktivitas bermain fisik seperti melakukan permainan tradisional engklek mampu mengoptimalkan tahapan perkembangan pada diri siswa ${ }^{18}$. Ditambah dapat mengenalkan siswa terhadap nilai-nilai budaya sunda yang semakin hari semakin dilupakan.

Respon siswa pada pernyataan 3 yakni berkaitan dengan pernyataan apakah siswa senang mengukur keliling persegi menggunakan tali atau tidak, diperoleh hasil pada implementasi tahap I yakni sebagian besar siswa menjawab dengan sangat setuju dan setuju. Namun, ada beberapa siswa yang tidak setuju. Sedangkan hasil pada implementasi tahap II yakni seluruh siswa menjawab sangat setuju ataupun setuju dan tidak ada yang menjawab tidak setuju, hal ini disebabkan karena siswa sebelumnya belum pernah melakukan aktivitas tersebut. Melalui aktivitas mencari keliling persegi menggunakan tali siswa akan memperoleh konsep secara utuh karena siswa mendapatkan konsep tersebut berdasarkan hasil mengkonstruksi pemahaman sendiri berdasarkan pada apa yang telah mereka lakukan melalui pengalaman langsung ${ }^{19}$.

Respon siswa pada pernyataan 4 yakni berkaitan dengan pernyataan apakah siswa aktif dalam kegiatan diskusi atau tidak. Maka, diperoleh hasil bahwa pada implementasi tahap I yakni sebagian besar siswa menjawab sangat setuju dan setuju. Namun, ada pula 2 orang siswa yang menjawab tidak setuju. Sedangkan pada implementasi tahap II seluruh siswa menjawab setuju. Artinya, siswa saat aktif dalam mengikuti proses pembelajaran. Dengan diterapkannya aktivitas diskusi dalam pembelajaran dapat menjadikan siswa lebih aktif, meningkatan hasil belajar siswa dan siswa dapat menerima dengan baik materi yang diajarkan 20.

18 Irma Risdiyanti and Rully C I Prahmana, "ETNOMATEMATIKA : EKSPLORASI DALAM PERMAINAN," Journal of Mathematics Education IKIP Veteran Semarang 2, no. 1 (2018): 1-11.

19 Sinan Olkun et al., "Psychometric Properties of a Screening Tool for Elementary School Student's Math Learning Disorder Risk," International Journal of Learning, Teaching and Educational Research 15, no. 12 (2016): 48-66.

${ }^{20}$ Raden Rizky Amaliah, Abdul Fadhil, and Sari Narulita, "Penerapan Metode Ceramah Dan Diskusi Dalam Meningkatkan Hasil Belajar PAI Di SMA Negeri 44 Jakarta," 
Respon siswa pada pernyataan 5 yakni berkaitan dengan pernyataan apakah siswa mampu mengerjakan soal dengan baik dan benar atau tidak. Maka, diperoleh hasil bahwa pada implementasi tahap I yang menjawab sangat setuju ada 12 orang siswa, yang menjawab setuju 3 orang dan yang menjawab sangat tidak setuju ada 1 orang siswa. Untuk implementasi desain tahap II 7 orang menjawab sangat setuju, 1 orang menjawab setuju dan 2 orang menjawab tidak setuju. Siswa yang menjawab tidak setuju, menandakan bahwa siswa tersebut merasa kesulitan dalam menyelesaikan soal yang diberikan. Maka, berdasarkan hal ini, guru melakukan antisipasi didaktis pedagogis dan membantu siswa dalam menyelesaikan soal-soal yang diberikan.

Respon siswa pada penyataan 6 yakni berkaitan dengan penyataan apakah siswa tidak suka dengan pembelajaran matematika, diperoleh hasil pada pelaksanaan desain tahap I, terdapat jawaban siswa yang beragam yakni 5 orang siswa menjawab sangat setuju, 1 orang siswa menjawab setuju, 5 orang siswa menjawab tidak setuju dan 5 orang siswa menjawab sangat tidak setuju. Sedangkan untuk implementasi desain tahap II, diperoleh jawaban siswa, terdapat 1 siswa menjawab setuju, 5 siswa menjawab tidak setuju, dan 4 siswa menjawab sangat kurang setuju. Terdapat pemerolehan jawaban yang berbeda pada implementasi tahap I dan tahap II terhadap minat siswa matematika.

Respon siswa pada pernyataan 7 yakni berkaitan dengan pernyataan apakah siswa merasa jenuh ketika mengikuti pembelajaran matematika. Maka, diperoleh hasil bahwa pada implementasi tahap I yang menjawab sangat setuju ada 6 orang siswa, yang menjawab setuju 6 orang, yang menjawab tidak setuju 2 orang siswa dan sangat tidak setuju ada 2 orang siswa. Untuk implementasi desain tahap II 2 orang menjawab setuju, 4 orang menjawab tidak setuju dan 4 orang menjawab sangat tidak setuju. Dalam implementasi tahap I masih banyak siswa yang merasa jenuh ketika mengikuti proses pembelajaran, hal ini disebabkan siswa merasa bosan saat kegiat an bermain engklek. Maka, berdasarkan hal ini peneliti merevisi aturan permainan agar tidak terlalu banyak pemain yang menyebabkan efektifitas waktu bermain kurang optimal ${ }^{21}$.

Respon siswa pada penyataan 8 yakni berkaitan dengan pernyataan apakah siswa tidak aktif dalam aktivitas diskusi. Maka, diperoleh hasil pada implementasi tahap I yang menjawab sangat setuju 5 orang siswa,

Studi Al-Qur'an; Membangun Tradisi Berfikir Qur'an 10, no. 2 (2014): 119-131, http://journal.unj.ac.id/unj/index.php/jsq/article/view/4441.

${ }^{21}$ Yunianto, Indra Prahmana, and Crisan, "Indonesian Mathematics Teachers' Knowledge of Content and Students of Area and Perimeter of Rectangle." 
setuju lorang siswa, tidak setuju 6 orang siswa dan 4 orang siswa menjawab sangat tidak setuju. Artinya, masih ada 6 orang siswa yang memang tidak mengikuti pembelajaran secara aktif dalam kegiatan diskusi. Sedangkan pada implementasi tahap II yang menjawab sangat setuju tidak ada, setuju ada 2 orang siswa dan yang menjawab tidak setuju dan sangat tidak setuju ada 8 orang. Artinya, sebagian besar siswa dapat mengikuti pembelajaran secara aktif melalui aktivitas diskusi ${ }^{22}$.

Respon siswa pada pernyataan 9 yakni berkaitan dengan pernyataan apakah siswa kesulitan dalam mengerjakan soal yang diberikan. Maka, diperoleh hasil pada implementasi tahap I yang menjawab sangat setuju ada 5 orang siswa, setuju 2 orang siswa, tidak setuju 7 orang siswa dan sangat tidak setuju 2 orang siswa. Berdasarkan hal ini, maka ada 7 orang siswa dari 16 orang siswa yang masih kesulitan dalam mengerjakan soal yang diberikan. Sedangkan pada implementasi tahap II yang menjawab sangat setuju tidak ada, setuju 3 orang siswa, tidak setuju 3 orang siswa dan sangat tidak setuju 4 orang siswa. Artinya, dari 10 orang siswa yang mengerjakan soal hanya ada 3 orang yang kesulitan dalam menyelesaikannya ${ }^{23}$.

Respon siswa terhadap pernyataan 10-15 berkaitan dengan manfaat penggunaan LAS dalam pembelajaran, berdasarkan hasil jawaban siswa pada impelementasi tahap I maupun tahap II, penggunaan LAS dalam pembelajaran membantu siswa dalam memahami materi keliling persegi dan mampu mengatasi learning obstacle yang dialami siswa pada materi tersebut. Secara umum, respon siswa pada implementasi tahap I dan II baik, siswa sangat terlihat menikmati setiap aktivitas pembelajaran, disisi lain guru pun meminta rancangan desain LAS yang telah dibuat oleh peneliti sebagai bahan referensi dalam penggunaan bahan ajar untuk memahamkan materi keliling persegi bagi siswa di sekolah dasar.

\section{PENUTUP}

Berdasarkan hasil penelitian, diperoleh simpulan sebagai berikut : Learning Obstacletipe 1, siswa tidak bisa mengidentifikasi konsep bangun datar persegi. Untuk mengatasi learning obstacle pada tipe 1, siswa

\footnotetext{
22 Amaliah, Fadhil, and Narulita, "Penerapan Metode Ceramah Dan Diskusi Dalam Meningkatkan Hasil Belajar PAI Di SMA Negeri 44 Jakarta."

23 Yauma Mulieda Amalya, Epon Nur'aeni, and Akhmad Nugraha, "Desain Didaktis Keliling Persegi Melalui Model Pembelajaran SPADE," PEDADIDAKTIKA: Jurnal Ilmiah Pendidikan Guru Sekolah Dasar 8, no. 1 (2021): 83-90, http://ejournal.upi.edu/index.php/pedadidaktika/index.
} 
ditugaskan mengerjakan soal pada LAS yang berkaitan dengan bangun datar, melakukan aktivitas bernyanyi, bermain engklek dan aktivitas analisis, dengan menganalisis bangun datar persegi melalui petak engklek.

Learning Obstacle tipe 2, siswa kesulitan dalam menghitung keliling persegi. Untuk mengatasi learning obstacle tersebut, siswa ditugaskan untuk melakukan aktivitas pengukuran pada persegi dengan menggunakan tali, dimana pengukuran tersebut dilakukan pada petak permainan engklek yang berbentuk persegi.

Learning Obstacle tipe 3, siswa mengalami hambatan saat menentukan rumus keliling persegi. Untuk mengatasi learning obstacle tersebut, siswa ditugaskan untuk menyelesaikan 1 soal pada aktivitas diskusi dengan menggambar sebuah persegi yang telah ditentukan panjang sisinya dan menghitung keliling persegi terebut.

Learning Obstacle tipe 4, siswa belum mampu menyelesaikan soal cerita/berbentuk masalah yang berkaitan dengan keliling persegi. Untuk mengatasi learning obstacle tersebut siswa ditugaskan menyelesaikan 2 soal cerita yang berkaitan dengan menghitung keliling persegi.

Maka dari itu, sesuai dengan penjelasan tersebut bahwa Learning Obstacle yang dialami siswa pada materi keliling persegi dapat diselesaikan dengan memberikan pemahaman siswa terhadap konsep sebelumnya secara utuh dan mendalam sehingga siswa siap mempelajari konsep yang baru dibarengi dengan penerapan desain didaktis yang disesuaikan dengan Learning Obstacle yang dialami siswa dengan tetap memperhatikan karakteristik siswa sekolah dasar yakni desain didaktis berupa bahan ajar dengan berbasis permainan tradisional engklek dalam model pembelajaran SPADE.

\section{DAFTAR PUSTAKA}

Amaliah, Raden Rizky, Abdul Fadhil, and Sari Narulita. "Penerapan Metode Ceramah Dan Diskusi Dalam Meningkatkan Hasil Belajar PAI Di SMA Negeri 44 Jakarta." Studi Al-Qur'an; Membangun Tradisi Berfikir Qur'an 10, no. 2014 (2014): http://journal.unj.ac.id/unj/index.php/jsq/article/view/4441.

Amalya, Yauma Mulieda, Epon Nur'aeni, and Akhmad Nugraha. "Desain Didaktis Keliling Persegi Melalui Model Pembelajaran SPADE." PEDADIDAKTIKA: Jurnal Ilmiah Pendidikan Guru Sekolah Dasar 8, no. 1 (2021): 83-90. http://ejournal.upi.edu/index.php/pedadidaktika/index.

Fauzi, Irfan, and Andika Arisetyawan. "Analisis Kesulitan Belajar Siswa Pada Materi Geometri Di Sekolah Dasar.” Jurnal Matematika Kreat 11, no. 1 
(2020): 27-35.

Herman, Tatang, Karlimah, and Komariah. Pendidikan Matematika 1. Bandung: UPI Press, 2007.

Kholiyanti, Arni. "Pembelajaran Matematika Dari Konkrit Ke Abstrak Dalam Membangun Konsep Dasar Geometri Bagi Siswa Sekolah Dasar." Mathematics Education Journal 1, no. 2 (2018): 40-46.

Kurniasih, Ary Woro, Isti Hidayah, and Mohammad Asikin. "Teacher Support for Eliciting Students Mathematical Thinking: Problem Posing, Asking Questions, and Song." International Journal of Learning, Teaching and Educational Research 19, no. 10 (2020): 265-285.

Lidinillah, Muiz Abdul Dindin. "Educational Design Research : A Theoretical Framework for Action," no. 1 (2012): 23.

Muslimin, Ratu Ilma Indra Putri, and Somakim. "Desain Pembelajaran Pengurangan Bilangan Bulat Melalui Permainan Tradisional Congklak Berbasis Pendidikan Matematika Realistik Indonesia Di Kelas IV Sekolah Dasar.” Jurnal KREANO3, no. 2 (2012): 100-112.

Nur'aeni, Epon. Konsep Dasar Geometri. Bandung: Hibah Buku UPI, 2016.

Nur' aeni, Epon, and dkk. Pengembangan Model Pembelajaran Geometri Berbasis Permainan Tradisional Kampung Naga Untuk Siswa Sekolah Dasar. Tasikmalaya: Penelitian Dana Dikti Tahun ke-2, 2019.

Nur'aeni, Epon, Oyon Haki Pranata, Muhammad Rijal Wahid Muharram, and Ika Fitri Apriani. "SPADE : Model Pembelajaran Geometri Di Sekolah Dasar." Indonesian Journal of Primary Education 4, no. 2 (2020): 81-88.

Olkun, Sinan, Arif Altun, Sakine Gocer Sahin, and Galip Kaya. "Psychometric Properties of a Screening Tool for Elementary School Student's Math Learning Disorder Risk." International Journal of Learning, Teaching and Educational Research 15, no. 12 (2016): 48-66.

Pantan, Frans, and Priskila Issak Benyamin. "Peran Keluarga Dalam Pendidikan Anak Pada Masa Pandemi Covid-19." Jurnal Teologi Pantekosta 3, no. 1 (2020): 13-24.

Pratiwi, Vira, Dian Indihadi, and Dindin Abdul Muiz Lidinillah. "Strategi Think Talk Write Untuk Pengembangan Kemampuan Komunikasi Matematis Siswa Pada Materi Perbandingan Di Kelas V SD." PEDADIDAKTIKA: Jurnal Ilmiah Pendidikan Guru Sekolah Dasar 2, no. 2 (2015): 243-258. 
Rauchwerk, Susan. "Learning Through Play in Speed School, an International Accelerated Learning Program." International Journal of Learning, Teaching and Educational Research 16, no. 6 (2017): 52-63.

Risdiyanti, Irma, and Rully C I Prahmana. "ETNOMATEMATIKA : EKSPLORASI DALAM PERMAINAN." Journal of Mathematics Education IKIP Veteran Semarang 2, no. 1 (2018): 1-11.

Sari, Permata Wulan, and Nyiayu Fahriza Fuadiah. "ANALISIS LEARNING OBSTACLE MATERI SEGITIGA." Jurnal Inovasi Pendidikan Matematika 2, no. 1 (2019): 21-29.

Suryadi, Didi. "Didactical Design Research (DDR) Dalam Pengembangan Pembelajaran Matematika." Prosiding Seminar Nasional Matematika STKIP Siliwangi Bandung (2013): 3-12.

Tastbita, Zeerin, Epon Nur'aeni, and Akhmad Nugraha. "Learning Obstacle Siswa Pada Materi Luas Daerah Persegi Panjang” 7, no. 2 (2020): 138-147.

Yunianto, Wahid, Rully Charitas Indra Prahmana, and Cosette Crisan. "Indonesian Mathematics Teachers' Knowledge of Content and Students of Area and Perimeter of Rectangle." Journal on Mathematics Education 12, no. 2 (2021): 223-238. 